Jadwiga Miszalska

Uniwersytet Jagielloński

\title{
Działalność tłumaczek a polski kanon literatury włoskiej: Waleria Marrené-Morzkowska i Zofia Ernstowa
}

"Once you start to look at translators rather than translations, several things can be done", stwierdza Anthony Pym w jednej ze swoich publikacji (Pym 2009: 32). $\mathrm{W}$ istocie $\mathrm{w}$ rozważaniach dotyczących czynnika ludzkiego w przekładzie w sposób automatyczny na pierwszy plan wysuwa się postać tłumacza. Chociaż coraz częściej korzystamy z programów tłumaczących, trudno sobie wyobrazić przekład, zwłaszcza literacki, bez jego udziału. Warto jednak zatrzymać się chwilę nad samym pojęciem tłumacza. Pym w swym kanonicznym już dziele Method in Translation History zwraca uwagę na fakt, iż może ono być rozumiane w różny sposób. Tłumacz w ujęciu abstrakcyjnym to pewna figura dyskursywna obecna w tekście, podmiot dokonujący przekładu, który może odpowiadać jednej lub wielu osobom. $Z$ drugiej strony pojęcie to desygnuje też zawód o określonym statusie społecznym, prawnym czy finansowym. Pyma jednakże - i my podążać będziemy tą ścieżką - interesuje tłumacz jako osoba fizyczna ze swoją konkretną historią; postać, której aktywność nie ogranicza się do działalności translatorskiej (Pym 2014: 160). Nie należą bowiem do rzadkości sytuacje, w których osoby parające się przekładem łączą tę działalność $\mathrm{z}$ innym zawodem czy funkcją: pisarza, dziennikarza, polityka, pedagoga czy naukowca. Usytuowanie tłumacza w sieci zależności społecznych, uwarunkowań natury ekonomicznej i politycznej czy choćby zdarzeń składających się na prywatny wymiar jego egzystencji nie może nie oddziaływać na jego poczynania translatorskie. 
W ostatnich latach owo uwarunkowanie często staje się przedmiotem studiów przekładowych. Wiele uwagi poświęca się roli tłumacza i marginesowi jego swobody w podejmowaniu decyzji w sytuacji uzależnienia od skomplikowanych mechanizmów rynku wydawniczego z jego uwikłaniem ekonomicznym i częstokroć politycznym, o czym pisał już przed niemal trzydziestoma laty André Lefevere. Interesujące jest też zagadnienie udziału różnych podmiotów w procesie translacji i określenie stopnia ich sprawczości (Milton, Bandia). Według Tuiji Kinnunen i Kaisy Koskinen sprawczość tłumacza zależy od dwóch zasadniczych czynników. Składa się na nią pewna indywidualna wewnętrzna dyspozycja, chęć działania (willingness) oraz zdolność do jego podjęcia uzależniona od realnych możliwości ograniczonych strukturą czyli mechanizmami władzy w jej różnych przejawach (ability) (Kinnunen, Koskinen 6). Sprawczość nie ogranicza się do zamiaru; wynika ona zawsze z działania (acting) i wykracza często poza zwykłe wykonanie zlecenia. Tłumacz może mieć wpływ na wybór tekstu do tłumaczenia, a także na to, w jaki sposób tekst ten zaistnieje w systemie docelowym (na przykład wybór medium).

Niniejszy artykuł poświęcony jest działalności przekładowej dwóch tłumaczek literatury włoskiej: Walerii Marrené-Morzkowskiej i Zofii Ernstowej. Warto zaznaczyć, że analiza ilościowa literatury tłumaczonej w Polsce niezbicie dowodzi, że przekład literacki był i jest w dużej mierze domeną „kobiecą”, a jak pisze Ewa Rajewska, działalność ta długo nie cieszyła się uznaniem (zwłaszcza, gdy była dziełem kobiet). Wielu luminarzy polskiej literatury, jak Boy-Żeleński czy Tuwim, uważało tłumaczki za niedouczone niewiasty, niemające nic innego do roboty, których jedyną kompetencją była - nie zawsze dostateczna - znajomość języka (Rajewska 269-270). Nie zatrzymamy się jednak nad tym zagadnieniem, które wymaga odrębnych, pogłębionych badań; postaramy się natomiast wykazać, że sprawczość w przypadku omawianych postaci nie ograniczała się jedynie do tłumaczenia. Chociaż żyły one w dwóch różnych epokach i dwóch różnych systemach politycznych, w których różny był społeczny status kobiety, a także inna była ich sytuacja życiowa, wskażemy w ich działalności pewne punkty wspólne, charakterystyczne dla wielu pisarek-tłumaczek, dziennikarek, popularyzatorek kultury.

Waleria Marrené-Morzkowska (1832-1903) pochodziła z zamożnej rodziny inteligenckiej, otrzymała wielostronne i szerokie wykształcenie niemające jednak charakteru regularnych studiów. Aktywna w kręgach literackich zbliżonych do Elizy Orzeszkowej i organizatorka salonu literackiego, sama była niezwykle płodną pisarką, autorką około czterdziestu powieści oraz licznych nowel, które publikowała zarówno w postaci książkowej, jak i w odcinkach na łamach prasy. Była dziennikarką, redaktorką pism kobiecych, takich jak „Mody paryskie” czy 
„Świt”, i autorką kilkuset artykułów dotyczących różnorodnej problematyki od zagadnień społecznych i pedagogicznych po tematy kulturowe i literackie ${ }^{1}$. Właśnie bogaty dorobek publicystyczny o tematyce literackiej zasługuje na szczególną uwagę. Marrené opublikowała wiele szkiców o charakterze przekrojowym dotyczących literatury polskiej i obcej, artykułów monograficznych poświęconych poszczególnym pisarzom, a także recenzji książek wydawanych w Polsce i za granicą. Jej działalność nie ograniczała się do pisarstwa, stała się jedną z ważniejszych postaci w kręgach emancypantek, walcząc o edukację kobiet (Falkowska). Tę bogatą działalność uzupełniała twórczość translatorska z języka francuskiego, włoskiego, angielskiego i niemieckiego.

Szeroki zakres zainteresowań i działalności Marrené sprawił, że jej teksty wykazują czasem pewną powierzchowność, co nie ujmuje im jednak wartości popularyzatorskiej. Tak o naszej tłumaczce pisała Orzeszkowa w niepozbawionym ironii liście do Teodora Tomasza Jeża:

Wykształconą jest szeroko, więcej szeroko niż gruntownie, jak to zresztą dzieje się zwykle z wykształceniem kobiecym zdobywanym na drodze samouctwa. Sposób myślenia pozytywistyczny, wolny od przesądów rodzaju wszelkiego [...] bystrość umysłu dostrzegająca szerokie kręgi zjawisk połączona z pewną niecierpliwością i niestałością myśli, przeszkadzającymi odkrywać zjawisk tych połączenia i zasadnicze podstawy $[. .$.$] nie wątpiąca nigdy ani o sobie i siłach swych ani o wartości$ swych prac [...] Cechą [jej] jest głębokie, żarliwe, nigdy nie chwiejące się uwielbienie dla wartości własnych prac autorskich [14.04.1880] (Orzeszkowa 94).

Chociaż dorobek literacki Marrené był przez współczesnych czasem oceniany krytycznie (Białobłocki 118-128), jej powieści znajdowały grono odbiorców i była ona postacią znaną, szanowaną w kręgach literackich. Dzisiaj wspominana jest $\mathrm{w}$ opracowaniach historycznoliterackich głównie $\mathrm{z}$ uwagi na działalność społecznikowską i dziennikarską, gdyż nawet jeśli jej teksty krytyczno-literackie cechuje pewna pospieszność sądów, o której wspominała Orzeszkowa, nie można jej odmówić ogromnego oczytania. Pisarka nie tylko doskonale znała klasyków, ale również z uwagą śledziła nowości wydawnicze ukazujące się w Europie.

Zainteresowania Marrené związane z literaturą włoską zaowocowały kilkunastoma tekstami dotyczącymi współczesnych jej pisarzy, jak Giuseppe

1 Informacje bio-bibliograficzne na podstawie „Nowego Korbuta” oraz PBs. 
Pitrè, Giovanni Verga, Giosuè Carducci, Felice Cavallotti, Giuseppe Giacosa, publikowanymi na łamach czasopism i gazet codziennych, między innymi „Wisły”, „Przeglądu Tygodniowego”, „Prawdy”, „Kłosów”, „Biblioteki Warszawskiej”, „Kuriera Warszawskiego”. Nie tylko sama tłumaczyła, ale również z uwagą śledziła przekłady z języka włoskiego autorstwa innych tłumaczy ukazujące się na polskim rynku, o czym świadczy przedmowa jej autorstwa do przekładu Malombry Antonia Fogazzara (Marrené 1901). Jej tłumaczenia z włoskiego nie obejmują pozycji książkowych, jak w przypadku tłumaczeń z francuskiego czy niemieckiego (przekładała Balzaca i Ibsena); są to teksty małych rozmiarów lub fragmenty drukowane w prasie. Większość z nich ukazała się na początku jej kariery literackiej, stanowiąc ilustrację do publikowanych tekstów krytycznych. W roku 1860 opublikowała bowiem w „Bibliotece Warszawskiej” trzy obszerne, przekrojowe omówienia literatury włoskiej wzbogacone przekładami autorów zaliczanych do szeroko pojętego romantyzmu: poetów Uga Foscola, Giacoma Leopardiego, Francesca Dall'Ongaro, Giuseppe Giustiego i dramaturga Giambattisty Niccoliniego (W.M. 1860). Zapewne pozytywistyczne zacięcie sprawiło, że w późniejszym okresie zainteresowała ją twórczość dwojga autorów, należących do kręgu werystów i poruszających w swych utworach problematykę społeczną, Giovanniego Vergi i Matilde Serao. To ona wprowadziła Vergę do polskiego obiegu czytelniczego, publikując w roku 1882 dwa pierwsze polskie przekłady jego tekstów. Na łamach „Nowin” ukazało się tłumaczenie noweli Cavalleria rusticana, która - przerobiona później na dramat, a następnie na libretto operowe - zyskała w Europie duży rozgłos, a w 44 numerze „Prawdy” wydrukowano jej tłumaczenie jednego z najważniejszych opowiadań sycylijskiego pisarza, Pane nero ${ }^{2}$. Marrené nie poprzestała tylko na przekładach i w roku następnym opublikowała w „Ateneum” obszerny esej przybliżający polskim czytelnikom twórczość tego ważnego autora (Marrené 1883). Interesujące jest, co wpłynęło na fascynację pisarki włoską kulturą, co decydowało o wyborze omawianych i tłumaczonych autorów. Niestety nie dysponujemy archiwum, które pomogłoby zrekonstruować „mikrohistorię” tłumaczki (Munday) i prześledzić wszystkie sytuacje decydujące o jej „sprawczości”. W zasobach polskich bibliotek ${ }^{3}$ zachowały się pojedyncze listy kierowane do ważnych postaci polskiego życia literackiego. W początkach pisarskiej kariery pisała do Józefa Ignacego Kraszewskiego z prośbą o ocenę przesłanego utworu. W późniejszym okresie zwracała się do

2 W roku 1884 opublikowała w „Dzienniku Łódzkim” jeszcze jedną nowelę Sycylijczyka - Rosso Malpelo.

3 W Bibliotece Jagiellońskiej, w Bibliotece PAn i PAU w Krakowie, w Bibliotece Ossolineum, w Bibliotece Narodowej w Warszawie. 
Henryka Sienkiewicza z wyrazami hołdu dla jego twórczości, pisała także do Narcyzy Żmichowskiej, Samuela Dicksteina, Marii i Felicjana Faleńskich czy Teofila Lenartowicza. Listy te dotyczą zazwyczaj bieżących spraw związanych z publikacją utworów lub aktualnymi wydarzeniami z życia literackiego. Jedyny obszerny zbiór jej listów zachował się w przechowywanym w Instytucie Badań Literackich archiwum Elizy Orzeszkowej, z którą łączyły pisarkę więzy przyjaźni. W korespondencji tej brak jednakże bezpośrednich odniesień do aktywności translatorskiej, która, jak się wydaje, często traktowana była jako dodatkowe źródło dochodu autorki (wciąż zmagającej się z trudnościami finansowymi), a czasami jako punkt wyjścia do publikacji o charakterze krytycznoliterackim.

Możemy się jednak domyślać, że orientacji pisarki w problematyce włoskiej sprzyjał fakt, że bywała w Italii. Jej podróże do Francji i Włoch w latach 1876-1880 związane były z karierą artystyczną córki Kamili, która próbowała sił jako śpiewaczka operowa. W latach następnych odwiedzała ją we Włoszech już jako panią Kamilę Laval, spędzającą tam wakacje. W roku 1882 Kamila wynajmowała nad Lago Maggiore willę, w której gościła matkę. Jak pisze w swych wspomnieniach, Marrené poznała wówczas mieszkającego w pobliżu poetę i dramaturga Felice Cavallottiego, z którym toczyła rozmowy o włoskiej literaturze (Morzkowska-Laval). To w trakcie tego pobytu, w sierpniu, Morzkowska pisze do Vergi list, w którym prosi o zgodę na publikację polskiego przekładu Pane nero. List odnaleziony przeze mnie w Biblioteca Regionale w Katanii (sygn. 3591) jest bodaj jedynym świadectwem bezpośredniego kontaktu tłumaczki z włoskim środowiskiem literackim. Nie wiemy, czy Verga odpowiedział na list Marrené. W katańskim archiwum brak jakichkolwiek śladów kontaktów pisarza z polskimi tłumaczami lub wydawcami, a na półkach jego osobistej biblioteki obok tłumaczeń na inne języki próżno szukać istniejących polskich wydań jego dzieł. W istocie utwory Vergi ukazujące się z końcem wieku XIX w zaborze rosyjskim są wydaniami pirackimi, jako że Rosja nie podpisała konwencji berneńskiej z 1886 roku o respektowaniu praw autorskich. Wydaje się zatem, że prośba o zgodę na przekład była raczej pretekstem - wszak Marrené opublikowała w tym samym roku inną nowelę Vergi, o której nie wspomina w liście. Chodziło raczej o nawiązanie kontaktu ze sławnym pisarzem, z którym, jak można wyczytać z listu, Marrené odczuwała pewne „pokrewieństwo dusz”

Egregio Signore, [...] È una cosa scritta con tanta realtà [...] che sembra di vedere le persone e le scene varie del dramma intimo [...] E da questo dramma si capisce lo stato morale, intellettuale e economico del popolo poiché se lo vede rappresentato non tra le nebbie della falsa poesia, ma con tutta la clarezza della verità. Ed io credo che la verità è sempre stata 
l'unica maestra del bello [...] Leggendo questo magnifico „Pane nero” vi ho trovato applicate tutte le mie idee sopra l'avvenire del romanzo e mi è venuta la voglia di farlo conoscere ai miei compatrioti, traducendolo in polacco. Dunque mi rivolgo a Lei, chiedendone la permissione [...], 8 agosto '82, Villa Bedone de la Signora Laval'

Kilka dni wcześniej Marrené pisze do Orzeszkowej list, w którym opisuje swój włoski pobyt. Choć mowa w nim o lekturach nowości, nie pada nazwisko Vergi, nie pojawia się też żadna aluzja do zamierzonego przekładu. Pisarka zapowiada natomiast, że chciałaby swe włoskie doświadczenia wykorzystać w korespondencjach zamieszczanych na łamach prasy. W istocie w roku 1882 ukazało się w „Nowinach” kilka jej Listów z Włoch.

Czytam też bardzo wiele, ma się rozumieć, same włoskie nowości i wtajemniczam się w ruch literacki, bardzo dziwny w swoim rodzaju z powodu małego rozwoju periodu romantycznego i odbicia literatury realistycznej francuskiej, który [sic!] był koniecznym następstwem wybryków romantyzmu. Stąd dziwne pomieszanie pojęć: bajronizm pojawia się w [...?] szkoły Zoli itp. W każdym razie jest tu wielkie i szybkie podniesienie umysłowego poziomu. Rozgałęziają się szkoły, wznoszą wyższe szkoły kobiece, reformują szkoły męskie. Spotkałam kilka wykształconych osobistości płci żeńskiej, a wszystko zapowiada, że młodsze pokolenie stanie pod tym względem na równi innych społeczeństw europejskich. Są to bardzo pocieszające symptomata, z którymi mam zamiar zapoznać nasze społeczeństwo w szeregu korespondencji, które będę w rozmaitych pismach pomieszczać [2 sierpnia 1882]5.

4 „Szanowny Panie, [...] To jest napisane z takim realizmem [...], że zdaje się nam widzieć postaci i sceny różne tego dramatu [...]. I ten dramat pozwala nam zrozumieć stan moralności, poziom intelektualny i sytuację ekonomiczną ludu, ponieważ widzimy to nie owiane mgłą fałszywej poezji, lecz w całej oczywistości prawdy. A ja sądzę, że prawda zawsze była jedyną nauczycielką piękna [...]. Czytając ten wspaniały „Czarny chleb”, odnalazłam w nim wszystkie moje wyobrażenia o tym, czym powinna być powieść, i zapragnęłam ukazać ten utwór mym rodakom, tłumacząc go na język polski. Zwracam się zatem do Pana z prośbą o pozwolenie [...], 8 sierpnia '82, Villa Bedone pani Laval". Rkps w Biblioteca Regionale w Katanii, sygn. 3591 (tłum. autorki artykułu - J.M.).

5 Archiwum Elizy Orzeszkowej Instytut Badań Literackich PAN. 
Podziw dla realizmu Vergi przebija $\mathrm{z}$ artykułu opublikowanego w „Ateneum”, stanowiącego obszerne omówienie twórczości pisarza (Marrené 1883). Marrené zorientowana jest w większości jego dorobku i wspomina wszystkie ważne utwory opublikowane do roku 1883: Storia di una capinera (1871), Eva (1873), Eros (1875) I Malavoglia (1881), Il marito di Elena (1882), niektóre nowele ze zbioru Vita dei campi (1880) oraz Pane nero wydaną oddzielnie w 1882, a następnie w zbiorze Novelle rusticane w 1883 roku. Autorka nie ogranicza się do krótkich streszczeń utworów i zamieszczenia fragmentów we własnym przekładzie, ale próbuje dokonać oceny estetycznej tej twórczości na tle ówczesnej literatury włoskiej, którą uważa za niezbyt interesującą. Nie negując wpływu pisarzy francuskich, Alfreda de Musseta w początkowych, a Emila Zoli w późniejszych utworach, podkreśla oryginalność Vergi, która z całą mocą przebija z tekstów osadzonych w sycylijskich realiach. Docenia trafność obserwacji zjawisk społecznych i ich wpływ na psychologię postaci, oddaną w sposób zwięzły i pozbawiony patosu. Ceni katańskiego pisarza właśnie za ową zwięzłość i za nieuleganie w opisach fascynacji brzydotą, co odróżnia go na korzyść od Zoli. Ocena przedstawiona przez autorkę nie odbiega od sądów współczesnych mu krytyków włoskich i od obrazu autora, jaki utrwalił się literaturze. Krytykowany za sztuczność swych pierwszych powieści osadzonych w „wyższych sferach”, Verga ceniony był za utwory sycylijskie tworzone zgodnie z poetyką weryzmu.

Tak Marrené porównuje obu pisarzy:

Jest on mniej pesymistyczny niż Zola, jeśli potrzebuje zaznaczyć jaki rys wstrętny, czyni to bez żadnej pruderii, ale nie lubuje się we wstrętnych obrazach, nie ma także tej rozwlekłości, którą niejednokrotnie zarzucano autorowi Nany; jest bez porównania zwięźlejszy, bardziej skupiony. Realizm czy naturalizm jego jest trzeźwiejszy i umiarkowany, nie ma w nim wybryków, które charakteryzują mistrza szkoły i czynią go raczej patologiem niż fizjologiem społecznym. Verga jako Włoch prawem narodowości posiada rozwinięty zmysł harmonii i to nadaje dziełom jego urok wykończenia (Marrené 1883: 231).

I jeszcze:

Jest on o wiele wstrzemięźliwszy [od Zoli], wydobywa plastykę swoich postaci prostymi, nieskomplikowanymi środkami. Nade wszystko należy podziwiać jego zwięzłość, nigdy nie ulega pokusie wmieszania się do akcji lub wtrącenia jakiejś refleksji. Zwięzłość ta i wstrzemięźliwość czyni bardziej przejmującymi dramatyczne sytuacje (Marrené 1883: 227). 
Nie wiemy, w jakiej mierze artykuł Marrené przyczynił się do późniejszej recepcji Vergi w Polsce. Faktem jest, że w latach 1884-189o wydano w Polsce wszystkie pięć powieści wspomnianych przez autorkę, a anonimowy przekład Storia di una capinera (1886) opatrzono zaproponowanym przez nią polskim tytułem Historia ptaka $w$ klatce, wcale nie oczywistym, gdyż niebędącym wiernym przekładem oryginału. W prasie natomiast ukazało się kilka nowelek w tłumaczeniu Marii Faleńskiej oraz anonima. Wydaje się także, iż krytyka polska nie poświęcała jeszcze Verdze wówczas wiele uwagi. Artykuły na temat sycylijskiego pisarza i innych werystów zaczęły się ukazywać w „Prawdzie” dopiero około połowy lat dziewięćdziesiątych. W roku 1891 Konstancja Morawska przedstawiła w „Przeglądzie Polskim” Storia di una capinera jako jedną z nowości włoskiej literatury, najwyraźniej nieświadoma faktu, że powieść ukazała się we Włoszech przed dwudziestoma laty i doczekała się pięć lat wcześniej polskiego tłumaczenia. Jej ocena utworu jest diametralnie różna od oceny Marrené. Morawska widzi w nim przede wszystkim niczym nieuzasadniony atak na klasztory, nie zdając sobie sprawy, iż utwór Vergi jest jednym z wielu głosów reakcji na żywy jeszcze we Włoszech zwyczaj monacazione forzata czyli umieszczania przez rodziców w klasztorach córek pozbawionych posagu. Zestawienie opinii tych dwóch autorek pozwala docenić oczytanie Marrené i postępowość jej poglądów.

Zofia Ernstowa z domu Kostanecka (1918-1994) ${ }^{6}$ przyszła na świat niemal sto lat później w zamożnej inteligenckiej rodzinie (ojciec był drugim rektorem Uniwersytetu Warszawskiego). Jeszcze przed wojną podjęła studia uniwersyteckie z ekonomii w Warszawie i z historii sztuki w Rzymie, których jednak nie skończyła. Przeszkodziła jej w tym wojna, a także względy osobiste: w roku 1938 wyszła za mąż za Jana Ernsta, doktora geografii ekonomicznej, a później profesora na uMCs w Lublinie. Częściowo to właśnie znajomości męża, który był również muzykiem, umożliwiły jej w pierwszych latach kontakty ze środowiskiem artystycznym w Łodzi, gdzie zamieszkali zaraz po wojnie, a potem w Warszawie. Ernstowie przyjaźnili się w owym czasie z takimi sławami jak Jan Brzechwa, Julian Tuwim, Antoni Słonimski czy Jarosław Iwaszkiewicz. W 1953 roku Ernstowa zadebiutowała jako tłumaczka i wstąpiła do Związku Literatów Polskich. Od tego czasu jej kariera translatorska zaczęła się szybko rozwijać. Dzięki znajomościom męża często bywała we Włoszech, gdzie spotykała ważne

6 Wszystkie informacje biograficzne czerpię z artykułu Katarzyny Biernackiej-Licznar (2017). 
postaci życia kulturalnego, z którymi nawiązała znajomości i przyjaźnie. Choć bardzo dobrze znała również języki francuski i angielski, była wyraźnie zafascynowana literaturą włoską i tłumaczyła tylko z tego języka. Szybko znalazła uznanie również we Włoszech, pełniąc od roku 1958 funkcję sekretarza sekcji polskiej Comes (Comunità Europea degli Scrittori); ponadto od 1964 była członkinią Pen-Clubu.

Dorobek przekładowy Ernstowej jest imponujący. Przetłumaczyła z włoskiego trzydzieści dziewięć powieści, siedem zbiorów opowiadań samodzielnie lub we współautorstwie, trzy tomy eseistyczne i 16 tekstów dramatycznych (Gurgul et al.; Miszalska et al.). Dramaty, opery i musicale mniej znanych współczesnych autorów, ale także noblisty Daria Fo wystawiane były w jej tłumaczeniu na scenach w całej Polsce. Jej dorobek translatorski jest bardzo zróżnicowany. Wśród tłumaczonych przez nią autorów znalazło się wielu pisarzy z kręgu neorealistów, których twórczość zgodna była z ówczesną ideologią obowiązującą w naszym kraju, a z których nie wszyscy przetrwali próbę czasu. Przeważają jednak pierwszoplanowe nazwiska dwudziestowiecznej włoskiej literatury, bez których trudno sobie wyobrazić jej całościowy obraz: Vitaliano Brancati, Italo Calvino, Carlo Cassola, Alba De Céspedes, Gianna Manzini, Elsa Morante, Alberto Moravia, Cesare Pavese, Leonardo Sciascia, Italo Svevo, Giuseppe Tommasi di Lampedusa. W jej dorobku znalazły się też dwie czołowe postaci weryzmu: Federico De Roberto i Giovanni Verga. Przetłumaczyła także kilka pozycji literatury dziecięcej; upodobała sobie zwłaszcza Gianniego Rodariego, niezwykle ciekawego pisarza o mocno lewicowych poglądach, lansowanego w Polsce za czasów PRL-u, ale czytanego do dzisiaj.

Zbieg okoliczności sprawił, że Ernstowa zadebiutowała właśnie przekładem tekstów Vergi, wprowadzonego do naszej świadomości literackiej przez Marrené. W 1953 roku wydała wraz z Marcinem Czerwińskim wybór opowiadań Sycylijczyka: Don Candeloro i jego trupa. Nowele, na który złożyło się 21 jeden opowiadań z różnych tomików. Ernstowa wzięła na warsztat cztery nowele z tomu Per le vie, cztery nowele $\mathrm{z}$ Vita dei campi i pięć $\mathrm{z}$ tomu Novelle rusticane, w tym Pane nero. Wśród jej tłumaczeń są wszystkie trzy opowiadania tłumaczone przez Marrené: oprócz Pane nero także Cavalleria rusticana i Rosso Malpelo. Opowiadania wyszły w wydawnictwie Czytelnik, z którym, obok PIw-u, głównie współpracowała. Działalność przekładowa Ernstowej została doceniona w Polsce i we Włoszech, tłumaczka była kilkakrotnie odznaczana przez zAiks i rząd włoski, a w roku 2016 przyznano jej nagrodę Leopolda Staffa „In memoriam”.

W przeciwieństwie do Marrené aktywność Ernstowej, mająca na celu popularyzowanie w Polsce włoskiej literatury, ograniczała się do przekładów. Tłumaczka nie pisała esejów, nie opatrywała nawet wstępami swych tłumaczeń. 
Niemniej jednak dobór przekładanych tekstów nie jest przypadkowy i świadczy o jej doskonałej orientacji we włoskiej literaturze. Potwierdzeniem tego jest fakt, iż powierzono jej przygotowywanie listy włoskich książek godnych tłumaczenia. Jak postaramy się wykazać, Ernstowa sama aktywnie zabiegała o publikacje książek, w jej przekonaniu, wartościowych.

Niestety nie zachowało się żadne archiwum tłumaczki, choć z całą pewnością możemy stwierdzić, że utrzymywała ona kontakty osobiste i listowe z niektórymi autorami włoskimi. Śladem takich kontaktów jest kilka listów odnalezionych w archiwum Alby de Céspedes, przechowywanych w archiwum Fondazione Mondadori w Mediolanie, czy list do Marii Bellonci z roku 1963 znajdujący się w zbiorze korespondencji pisarki przechowywanym w Biblioteca Nazionale w Rzymie.

Listy odnalezione w archiwum wydawnictwa Mondadori pochodzą z lat 1962-1964; 1967-1969; 1988/89?: sześć listów Zofii do Alby i osiem kopii listów Alby do Zofii. Są one świadectwem nie tylko osobistych kontaktów, znajomości, która przeradza się w przyjaźń, ale też zabiegów czynionych przez tłumaczkę w celu sfinalizowania polskich wydań utworów de Céspedes ${ }^{7}$. Alba de Céspedes po debiucie w 1938 roku bestsellerową powieścią Nessuno torna indietro aż po lata siedemdziesiąte znajdowała się wśród najczęściej tłumaczonych włoskich pisarzy. Wspomniana wyżej powieść po pierwszym przekładzie na język węgierski w 1939 roku doczekała się w sumie tłumaczeń na 21 języków w 19 krajach (di Nicola 422-425). W Polsce ukazało się jej sześć pozycji: pięć powieści i zbiór opowiadań. Ernstowa przetłumaczyła tylko jedną powieść, Il quaderno proibito (Brulion Walerii Cossati, Iskry 1961), korespondencja z autorką dowodzi jednak, że interesowała się innymi tekstami i czyniła zabiegi o możliwość ich publikacji. Powodzenie projektu translatorskiego zależne było od kilku czynników: należało uzyskać zgodę autora na przekład, przekonać go, aby przystał na sposób wypłacenia części honorarium w złotówkach (do wykorzystania w czasie pobytu w Polsce), a następnie umieścić przekład w planach danego domu wydawniczego. Umieszczenie w planie uzależnione było nie tylko od akceptacji danej pozycji (w tym przychylnej opinii cenzorskiej), ale też od środków finansowych na działalność wydawnictw reglamentowanych przez państwo. Wszystkie te zawiłości realnego socjalizmu Ernstowa wyjaśnia pisarce w swej korespondencji. Bardzo zależy jej na rozpowszechnieniu w Polsce twórczości De Céspedes, którą bardzo ceni. Po wydaniu książkowym Quaderno proibito prosi o zgodę na druk w czasopiśmie:

7 W archiwum znajdują się też listy innych tłumaczy: Maksymiliana Pelińskigo i Ewy Szelchauz, będące świadectwem podobnych inicjatyw. 
[15.05.1962] Carissima Amica, la ringrazio molto del suo gentile permesso di stampare il „Quaderno proibito” a puntate con il compenso in zloty. Ne sono molto felice; il settimanale „Przyjaciółka” ha la tiratura di due milioni di copie cioè per Lei due milioni di nuove lettrici... ${ }^{8}$ (AdC b.16 f.1).

W następnych latach Ernstowa stara się o uzyskanie praw do tłumaczenia i do wydania powieści Il rimorso i La bambolona, jednak nie udaje się jej sfinalizować projektu:

[27.04.1964] Ho telefonato alle case editrici principali (PIW, Czytelnik, Iskry) per avere le notizie de „Il rimorso”. La traduzione non è prevista nel piano editoriale 1964-65. Vedremo per l'anno prossimo. Io tradurrei con entusiasmo il suo libro; mi piace moltissimo... ${ }^{9}$ (AdC b.16 f.1 sf.6).

Il rimorso, na które brakowało funduszy, ukazało się w roku 1982 w tłumaczeniu (zresztą tak fatalnym, że wymagało korekty w trakcie prac redaktorskich) Ewy Szelchauz (Wyrzuty sumienia, Wyd. Literackie). W przekładzie powieści La bambolona ubiegła natomiast Ernstową Halina Kralowa:

[4.01.1968] Io ho proposto il libro [„La bambolona”] alla casa editrice Czytelnik che mi abbia [sic!] dato la risposta positiva e voleva stamparlo. Risulta però che i diritti della stampa di codesto libro ha ormai un'altra casa editrice PIW e lí „La bambolona” è stata portata mesi fa da una signora tornata da un viaggio in Italia che lo vuole tradurre. Siccome ha dato il libro per prima, la precedenza fu data a lei ${ }^{10}$ (AdC b.16 f.1 sf.9).

8 „Droga Przyjaciółko, dziękuję, że zgodziła się Pani na druk «Quaderno proibito» w odcinkach i honorarium w złotych. Bardzo jestem szczęśliwa, tygodnik «Przyjaciółka» ma nakład dwóch milionów egzemplarzy, co znaczy, że zyska Pani dwa miliony nowych czytelniczek..." [15.05.1962]. Wszystkie cytowane listy z korespondencji Ernstowej pochodzą z Archiwum Alby de Céspedes (AdC) przy Fondazione Mondadori w Mediolanie. Przekłady autorki artykułu - J.M.

9 „Dzwoniłam do wydawców (PIw, Czytelnik, Iskry) aby dowiedzieć się o «Il rimorso». Przekład nie jest przewidziany w planie wydawniczym 1964-65. Zobaczymy, jak będzie w przyszłym roku. Ja bardzo chętnie przetłumaczę Pani książkę, bo bardzo mi się podoba..." [27.04.1964]

10 „Zaproponowałam książkę [«La bambolona»] wydawnictwu Czytelnik, które dało pozytywną odpowiedź i chciało ją wydać. Okazało się jednak, że prawa do druku ma już inny wydawca, PIw, i że książkę przyniosła kilka miesięcy temu pewna pani, która co 
Rozczarowana tłumaczka proponuje przekład teatralnej adaptacji powieści, która - jak pisze de Céspedes - święci triumfy we Włoszech. Wydaje się jednak, że do przekładu i wystawienia polskiego nie doszło, nie zrealizowano też przedstawienia scenicznego Quaderno proibito, choć Ernstowa w liście z dn. 15 maja 1962 roku wspomina o pracy nad przekładem. W trakcie swej znajomości z Albą De Céspedes tłumaczka próbowała jeszcze doprowadzić do wydania debiutu włoskiej autorki Nessuno torna indietro, którego publikacji przeszkodziła wojna. Wydawnictwo Mondadori podpisało bowiem w 1939 roku umowę z warszawskim wydawnictwem „Renaissance”, która nigdy nie została zrealizowana. Wprawdzie powieść wyszła w 1947 roku w odcinkach na łamach „Echa Krakowa”, ale z uwagi na zmieniony tytuł (Na drugim brzegu) ani autorka, ani tłumaczka, ani też wydawcy nie znali tego pirackiego, anonimowego przekładu dokonanego z języka niemieckiego (Miszalska 227-228).

Jak wynika z dokumentów przechowywanych w Archivio Mondadori, ponowne próby wydania powieści rozpoczęły się już w 1948 roku w sytuacji względnej swobody na rynku wydawniczym. Mondadori sprzedał prawa związanemu z PPS wydawnictwu „Wiedza” w Warszawie, planu wydawniczego jednak nie zrealizowano, gdyż wydawnictwo zostało połączone z PPR-owską „Książką”, tworząc „Książkę i Wiedzę”. W korespondencji z roku 1968 roku pojawia się natomiast propozycja przekładu ze strony pisarki (list z 17 lutego) i w roku następnym Ernstowa proponuje książkę wydawnictwu „Czytelnik” (list Z 27 lutego 1969). Również tym razem planu nie udaje się zrealizować, a projekt powraca raz jeszcze w korespondencji z lat 1987-1988, gdy tłumaczka informuje, że „Książka i Wiedza” decyduje się na wydanie powieści. Jednak nad książką zdaje się ciążyć fatum. Nadchodzi rok 1989 ze zmianami własnościowymi, które dotykają też rynku książki, i zapaścią przemysłu wydawniczego. Urywa się również korespondencja między autorkami.

Mia carissima Zofia, l'arrivo della tua lettera è stata una festa per me che non avevo tue notizie da tanto tempo. La tua lettera mi è pervenuta grazie al mio editore parigino, Le Seuil che ha fornito indirizzo e Ti rispondo immediatamente [...] Nessuno torna indietro seguita ad essere ristampato in Italia e all'estero, come se fosse una novità benché il 17 dicembre del 1988 saranno cinquanta anni dalla sua prima pubblicazione, stampata da Mondadori. [...] Non perdiamoci ora che ci siamo ritrovate! Ti voglio bene, Ti ringrazio e con molti auguri per

dopiero wróciła z Włoch i chce ją przetłumaczyć. Ponieważ pierwsza zaproponowała książkę, to ona ma pierwszeństwo...”[4.01.1968]. 
la Tua salute ed il Tuo lavoro, Ti abbraccio affettuosamente ${ }^{11}$ (AdC b. 18 , f. 2).

Cytowany list jest ostatnim świadectwem kontaktów między Albą de Céspedes i Zofią Ernstową. Polska tłumaczka odchodzi w 1994 roku, pozostawiając czytelnikom skarb nie do przecenienia w postaci swoich świetnych przekładów.

Marrené-Morzkowska i Ernstowa działały w różnych momentach historii naszego kraju, a ich działalność wpisywała się w zupełnie inny ład instytucjonalny. Polska końca XIX wieku nie dysponowała narodowymi instytucjami kultury. Wszelkie przedsięwzięcia podejmowane w trzech zaborach miały charakter mniej lub bardziej prywatny, będący w przypadku czasopism i wydawnictw wypadkową przekonań i zainteresowań zespołu redaktorów, na dodatek ograniczanych warunkami finansowymi i niejednokrotnie ingerencjami cenzorskimi zaborców. Nie istniał zatem jakikolwiek plan wydawniczy, brakowało również organizacji, które skupiałyby grono osób odpowiedzialnych za politykę kulturalną, w tym tłumaczy. Rzeczywistość instytucjonalna, a także technologiczna, w której przyszło działać Ernstowej, była całkowicie inna. Istniał już szereg gremiów skupiających autorów i tłumaczy, umożliwiających nawiązywanie kontaktów i wymianę poglądów, $\mathrm{z}$ drugiej strony w warunkach PRL-u przemysł wydawniczy był silnie scentralizowany i podlegał planowaniu, co stanowiło przeszkodę dla wielu inicjatyw. Podczas gdy z końcem wieku XIx możemy mówić w kulturze o tak zwanym patronacie zróżnicowanym (różne źródła finansowania, niejednorodność ideologiczna instytucji kultury), co nie oznaczało jednak całkowitej swobody działania, w okresie po II wojnie światowej polska kultura działała w sytuacji patronatu jednorodnego (Lefevere 11-25). Władza polityczna i ekonomiczna skupiona była w jednym ręku, a zaakceptowanie planu wydawniczego zależało zarówno od oceny cenzorskiej, jak i od przyznania środków materialnych (w sytuacji ciągłych braków finansowych i niedoboru papieru). nie miałam od Ciebie wiadomości. List doszedł do mnie dzięki wydawcy paryskiemu Seuil, który udostępnił adres i od razu Ci odpisuję [...]. Nessuno torna indietro dalej wydawana jest we Włoszech i za granicą jakby była jakąś nowością choć 17 grudnia 1988 minie 50 lat od pierwszego wydania przez Mondadori [...]. Nie zgubmy się znowu po tym, jak się odnalazłyśmy. Kocham Cię, dziękuję Ci, życzę dużo zdrowia i wszystkiego najlepszego w pracy. Ściskam cię serdecznie". 
Co zatem łączy obie autorki i jaki sens ma zestawienie dwóch postaci - wydawałoby się - tak różnych i czasowo odległych? Marrené i Ernstowa jawią się jako postaci ważne czy wręcz emblematyczne na mapie polsko-włoskich kontaktów literackich. Marrené była autorką pierwszego polskiego przekrojowego szkicu o literaturze Półwyspu (W.M. 1860) i uważną obserwatorką włoskiego życia literackiego w ostatnich dekadach XIx wieku. Ernstowej nie wahałabym się nazwać najbardziej zasłużoną tłumaczką literatury włoskiej. Łączy je ponadto wyjątkowy zapał i determinacja w popularyzacji literatury Italii pomimo niełatwych warunków, w których przyszło im działać.

Czy zatem w świetle przedstawionych faktów cytowany na wstępie sąd o przekładowej działalności kobiet znajduje potwierdzenie w przypadku bohaterek naszego artykułu? W ciągu niemal stu lat dzielących ich twórczość zmieniła się społeczna pozycja kobiety, możliwość zdobycia wykształcenia, akceptacja dla działalności zawodowej, a przecież sarkastyczne stwierdzenie Tuwima: „Gdy wszystkie inne możliwości zarobkowania odpadną, osoba przypomina sobie, że "posiada języki»" ukazało się drukiem w okresie, w którym druga z tłumaczek rozpoczynała swą działalność translatorską (Tuwim 167). Obie autorki - mimo że nie ukończyły regularnych studiów - dzięki kontaktom kulturalnym i własnej determinacji zdobyły szeroką wiedzę literacką, choć Ernstowa skoncentrowała się wyraźnie na środowisku włoskim. Obie też pojmowały swą pracę jako misję popularyzatorską: ta pierwsza przede wszystkim poprzez krytykę literacką wspomaganą przez przekład, ta druga w zasadzie wyłącznie przez tłumaczenia. Jak wspomniano wcześniej, Ernstowa nie pisała o literaturze, co nie znaczy, iż nie miała wyrobionego zdania na temat wartości dzieła literackiego. Z listów do Alby de Céspedes dowiadujemy się, że przygotowywała dla wydawnictwa omówienia książek proponowanych do przekładu i prosiła o przysyłanie włoskich artykułów krytycznych na ich temat. W rozmowie przeprowadzonej w roku 1974 z Eugeniuszem Kabatcem wspomina o swym uczestnictwie w komisji powołanej przez Klub Tłumaczy Związku Literatów Polskich w celu przygotowania listy obcych książek zalecanych do wydania w Polsce:

Mamy luki, które trzeba pouzupełniać. Zostały opracowane listy najważniejszych pozycji, których brak na polskim rynku księgarskim został uznany jako zubożenie naszej świadomości kulturalnej, jak się wyraziłeś, a także nie daje pełnego przekroju literatur poszczególnych krajów (Kabatc 383).

Obie tłumaczki w sposób oczywisty pojmowały swoją działalność szerzej niż jako proste wykonanie zlecenia. To one dokonywały wyboru, kierując się 
swym sądem estetycznym i potrzebami kultury rodzimej. Nie szczędziły téz sił na działanie czysto organizacyjne. Marrené prowadziła w Warszawie salon literacki i podejmowała wysiłki w tworzeniu literackich czasopism kobiecych. Ernstowa jako pierwsza Polka stała się członkiem Comes, później piastując funkcję sekretarza polskiej sekcji. Ich sprawczość nie ograniczała się tylko do przekładania tekstu; były autorkami wielu inicjatyw i starały się - w ramach możliwości oferowanych przez system - konsekwentnie realizować założony cel, jakim było przyswojenie polskiemu czytelnikowi dzieł włoskich pisarzy i tym samym budowanie kanonu literatury Italii.

\section{| Bibliografia}

Białobłocki, Bronisław. „Miłość w sferze dostatków i estetycznych zachwytów”. Szkice społeczne i literackie. Oprac. S. Sandler. Warszawa: Czytelnik, 1954. S. 117-129.

Bibliografia Literatury Polskiej „Nowy Korbut” . T. 8: „Romantyzm”. Warszawa: PIW, 1969.

Biernacka-Licznar, Katarzyna. „Zofia Ernstowa (1918-1994): Larte di vivere. Larte di tradurre". Italica Wratislaviensia 8(2) (2017). S. 11-16.

di Nicola, Laura. „Bibliografia”. Alba de Céspedes. Red. M. Zancan. Milano: Mondadori, 2005. S. 421-482.

Falkowska, Joanna. Ambasadorki wychowania. Poglady pedagogiczne polskich kobiet w II połowie XIX wieku i początkach XX wieku. Toruń: Wyd. Naukowe Uniwersytetu Mikołaja Kopernika, 2018.

Gurgul Monika, et al. Od Dantego do Fo. Włoska poezja i dramat w Polsce (od XVI do XXI wieku). Kraków: Collegium Columbinum, 2007.

Kabatc, Eugeniusz. „O przekładach literatury włoskiej. Rozmowa z Zofią Ernstową". Literatura na świecie 1 (33) (1974). S. 383-387.

Kinnunen Tuija, Koskinen Kaisa. “Introduction”. Tanslator's agency. Red. T. Kinnunen, K. Koskinen. Tampere: Tampere University Press, 2010. S. 4-9.

Lefevere, André. Translation, Rewriting and the Manipulation of Literary Fame. London-New York: Routledge, 1992.

W.M. [Marrené, Waleria]. „Literatura włoska. Rzut oka na obecne piśmiennictwo". Biblioteka Warszawska 1 (1860). S. 133-150, 376-390, 547-569.

Marrené, Waleria. „Przedmowa”. Fogazzaro, Antonio, Malombra. Przeł. Szet. Warszawa. Brak wyd., 1901.

Marrené, Waleria. „Z życia włoskiego. Giuseppe Verga”. Ateneum 1, z. 2 (1883). S. 219-234. 
Milton John, Bandia Paul. "Introduction: Agents of translation and Translation Studies". Agents in Translation. Red. J. Milton, P. Bandia. Amsterdam: John Benjamins, 2009. S. 1-17.

Miszalska, Jadwiga. "I personaggi sdoppiati in Nessuno torna indietro di Alba de Céspedes e le vicende tedesco-polacche del romanzo". Kwartalnik Neofilologiczny 2 (2019). S. 223-229.

Miszalska Jadwiga, et al. Od Boccaccia do Eco. Włoska proza narracyjna w Polsce (od XVI do XXI wieku). Kraków: Collegium Columbinum, 2011.

Morawska, Konstancja. „Kronika literacka”. Przegląd Polski 3 (1891/1892).

S. 241-242.

Morzkowska-Laval, Kamila. „Nie tylko w Zbożennie. Wspomnienia z Polski, Włoch i Francji”. Pani Na Sycynie, cz. III Z dziejów rodziny. Red. K. Czapliński. Wrocław-Janowiec nad Wisłą: Towarzystwo Przyjaciół Janowca nad Wisłą, 2005. S. 61-156.

Munday, Jeremy. "Using Primary Sources to Produce a Microhistory of Translation and Translators. Theoretical and Methodological Concerns". Translator: Studies in Intercultural Communication 1 (2014). S. 64-80.

Orzeszkowa, Eliza. Listy zebrane. T. 6. Wrocław: Zakład im. Ossolińskich, 1967.

Pym, Anthony. "Humanizing Translation History". Hermes. Journal of Language and Communication Studies 42 (2009). S. 23-48.

Pym, Anthony. Method in Translation History. Wyd. 2. New York-London: Routledge, 2014.

Rajewska, Ewa. „Twórczość przekładowa kobiet”. Polskie pisarstwo kobiet w wieku xx: procesy, gatunki, sytuacje i tematy. Red. E. Kraskowska, B. Kaniewska. Poznań: Wydawnictwo Naukowe UAM, 2015. S. 270-277.

Tuwim, Julian. "Traduttore - traditore”. Pegaz dęba. Wyd. 3. Warszawa: Iskry, 2006. S. 165-190.

W. M. [Marrené, Waleria]. „Literatura włoska. Rzut oka na obecne piśmiennictwo". Biblioteka Warszawska 1 (1860). S. 133-150, 376-390, 547-569.

Wyczańska, Irena. „Waleria Marrené-Morzkowska”. Polski Słownik Biograficzny. T. 2o. Wrocław-Warszawa-Kraków-Gdańsk: Zakład Narodowy im. Ossolińskich, 1975. S. 60-62. 


\section{| Abstrakt \\ Jadwiga Miszalska \\ Działalność tłumaczek a polski kanon literatury włoskiej: Waleria Marrené-Morzkowska i Zofia Ernstowa}

Waleria Marrené-Morzkowska (1832-1903), pisarka, dziennikarka i tłumaczka oraz Zofia Ernstowa (1918-1994), autorka kilkudziesięciu tłumaczeń literatury włoskiej, działały w odległych momentach historycznych, niełatwych dla polskiej kultury narodowej. Zarówno w okresie rozbiorów, jak i w czasach PRL-u wiele inicjatyw na polu kultury dochodziło do skutku jedynie dzięki determinacji jednostek. Źródła przechowywane we włoskich i polskich archiwach pozwalają częściowo zrekonstruować „mikrohistorię” przedstawionych tłumaczek, ich kontakty z włoskimi pisarzami oraz wysiłki podejmowane w Polsce w celu udostępnienia polskiemu odbiorcy ważnych dzieł literatury włoskiej. Jak wynika z prowadzonych badań, sprawczość tłumaczek nie ograniczała się jedynie do wykonania przekładu, ale polegała na aktywnym uczestnictwie w doborze dzieł i ich promocji, przyczyniając się w ten sposób do tworzenia polskiego kanonu włoskiej literatury.

Słowa kluczowe: W. Marrene-Morzkowska, Z. Ernstowa, sprawczość tłumacza, mikrohistoria tłumacza, kanon literacki

\section{| Abstract}

JaDWiga Miszalska

Translator's Activity and the Italian Literary Canon in Poland: Waleria Marrené-Morzkowska and Zofia Ernstowa

Waleria Marrené-Morzkowska (1832-1903), writer, journalist and translator, and Zofia Ernstowa (1918-1994), author of several dozen translations from Italian literature, were active in two (distinct) historical moments that were not easy for the Polish culture. During the partitions as well as in the times of the Polish People's Republic many cultural initiatives were undertaken thanks to the determination of individuals. The archival materials preserved in Italy allow to reconstruct their microhistory, contacts with the Italian writers and activities in Poland that aimed at printing the selected works, constituting proof that the translator's agency is not limited to execution of the commissions but often involves active participation in selecting the works for translation in order to create a literary canon. 
Keywords: W. Marrene-Morzkowska, Z. Ernstowa, translator's agency, translator's microhistory, literary canon

\section{| Nota o autorze}

Jadwiga Miszalska - prof. zw. w Instytucie Filologii Romańskiej u i kierownik Zakładu Filologii Włoskiej. Jej zainteresowania naukowe dotyczą literatury włoskiej, włosko-polskich relacji kulturalno-literackich na przestrzeni wieków oraz przekładu literackiego w kontekście historycznym, a także figury kobiety jako tłumaczki i propagatorki kultury włoskiej w Polsce na przełomie xIx i xx wieku. Jest współautorką bibliografii przekładów literatury włoskiej w Polsce od wieku XVI po czasy współczesne oraz panoramy dawnego teatru włoskiego. Opublikowała ponadto m.in. następujące pozycje książkowe: „Koloander wierny” i „Piękna Dianea" polskie przekłady włoskich romansów barokowych w wieku XVII $i$ w epoce saskiej na tle ówczesnych teorii romansu i przekładu, Kraków 2003; I manoscritti italiani della collezione berlinese conservati nella Biblioteca Jagellonica di Cracovia (sec. XVII-XIX), Kraków 2012; Tragicznych igrzysk pieśń uczy nas cnoty. Przekłady z języka włoskiego jako źródło polskiej dramaturgii poważnej do końca XVIII wieku, Kraków 2013; Z ziemi włoskiej do Polski. Przekłady z literatury włoskiej w Polsce do końca XVIII wieku, Kraków 2015.

E-mail: jadwiga.miszalska@uj.edu.pl 